\title{
Postcards from Metro America: Reflections on Youth Participatory Action Research for Urban Justice
}

\section{Michelle Fine}

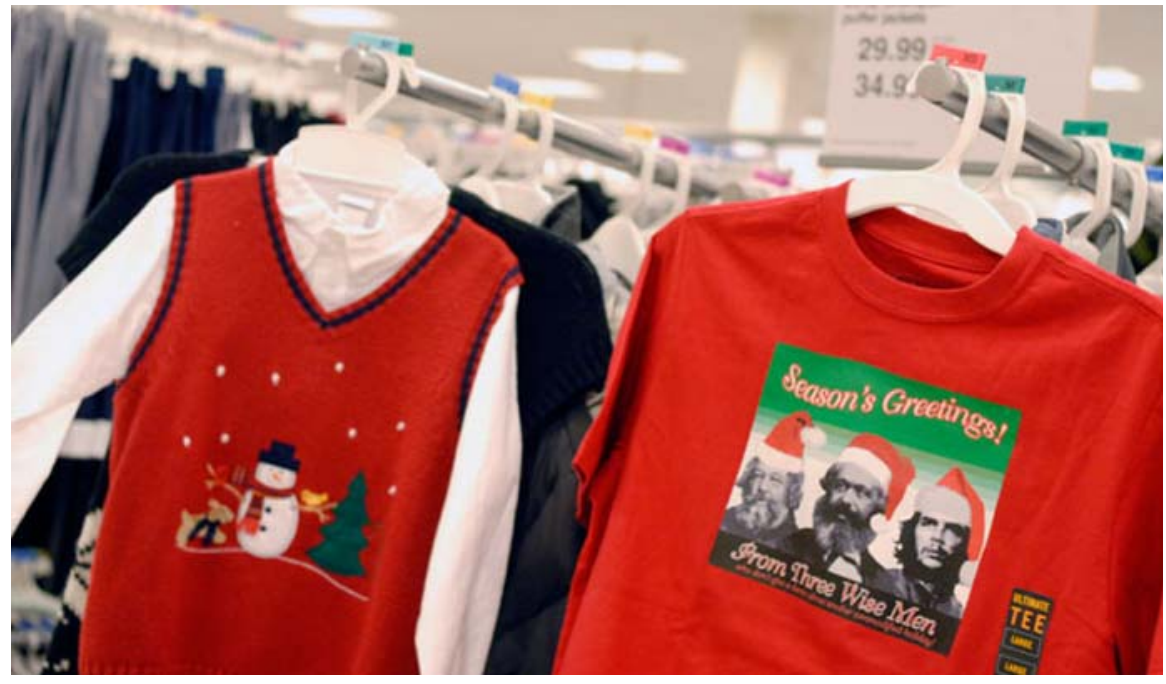

This week an arts group in Oakland, the Center for Tactical Magic, began shopdropping neatly folded stacks of homemade T-shirts into Wal-Mart and Target stores in the San Francisco Bay Area. The shirts feature radical images and slogans like one with the faces of Karl Marx, Che Guevara and Mikhail Bakunin, a Russian anarchist. It says, "Peace on Earth. After we overthrow capitalism." New York Times, 12/24/07, A5

Hard to believe that Target and Wal-Mart are selling t-shirts to warn consumers of capitalism's destructive appetite, or is this simply a[nother] commodification of radical ideas and images designed to inspire shopping? The t-shirt itself is an

M. Fine $(\bowtie)$

Psychology, Women's Studies and Urban Education, The Graduate Center at the City University of New York, New York, NY, USA

e-mail: mfine@gc.cuny.edu 
"empty" signifier. Perhaps it is a critical intervention into shopping madness or a trendy product to seduce consumers.

Like this t-shirt, we worry that Participatory Action Research (PAR) could become an "empty signifier" or a trendy method for co-opting urban youth into social research. With this volume of Urban Review, the six authors-all my students at one point or another-seek to resurrect and reflect on the radical beginnings, delicate practices and strong commitments of youth participatory action research (yPAR) as a form of theoretically grounded research, designed in social struggle, with youth and families, for racial, ethnic, gendered, sexual and economic justice in urban America.

\section{The Right to Research, Contest and Act}

"to act is to be committed and to be committed is to be in danger."

James Baldwin

Conceived as a tool of research for social protest and action, Participatory Action Research has long historic roots in Central and South America, sprouts in Asia, Africa, Australia, Europe and the United States. Across the globe, PAR collectives of youth, educators, organizers, women and men in prison and other activists gather to incite empirically inspired activism (see Appadurai 2006; Fine et al. 2007; Lykes and Mallona 2008; Rahman 2008). Within the US, particularly in urban centers, radical, vibrant and provocative campaigns of PARers have gathered evidence to challenge unfair labor and educational policies, mass incarceration, constraints on youth human rights, immigration violations, educational inequity, police brutality and discrimination against LGBTQ youth, to name a few hot spots of PAR (see Cammarota and Fine 2008; Reason and Bradbury 2008) Launched from community based organizations, schools and universities, these campaigns have been rooted in participation, inquiry, contestation and action.

Across venues and continents, Participatory Action Research (PAR) assumes that critical expertise lies in those most oppressed. At its heart, PAR insists that those persons who have been most structurally disenfranchised have, what Arjun Appadurai (2006) calls "a right to research" the conditions of their oppression and their resistance. PAR also embodies a radical commitment to inquiry-inspired action. But like the T-shirts in the opening of this essay, PAR has recently been appropriated by governments and corporations as a strategy to induce compliance and consent from people without much power to say No. Youth and adults living in poverty, Indigenous peoples, poor farmers and others have been invited into processes that extract knowledge from them, turning corporate profits. Much has been written on the "tyranny of PAR" as it gains global prominence (see Hickey and Mohan 2004). Before PAR hollows into a tool for hegemonic interests, we offer up this set of powerful and reflective essays on PAR and Critical Race Theory as enacted in a series of participatory projects with/by urban youth. 
In this volume, six young critical scholars, from the fields of psychology and education, pivot our focus onto participatory action research projects created to document and advocate at the intersection of human rights and educational justice. You might think of them as scribes sending postcards from Metro-America, stretching from state-neglected inner city neighborhoods to the mainline of elite suburbia.

These quantitative and qualitative accounts have been crafted by participatory collectives of researchers engaged in conversation with Critical Race Theories (CRT), including whiteness studies (see Stoudt), the streets as a site of resiliency (see Payne), Indigenous epistemologies (see Tuck), mestiza consciousness (see Ayala and Torre) and Freire's critical consciousness (see Guishard). Across projects you will bear witness to conditions of grotesque inequity and you will also delight in the resilient defiance rising up throughout urban America. Although inspired in very distinct settings and drawing from extremely divergent theoretical perspectives, these projects share four fundamental beliefs nurtured at the intersection of Participatory Action Research and Critical Race Theories:

- Youth grow up in profoundly uneven developmental contexts. These analyses of youth development are all situated within an understanding of the uneven racialized and classed geography of resources and opportunities in which youth grow up in contemporary America; with acute recognition of the differential contexts available to youth based on their position within the political economy, racism, swelling gaps between rich and poor, histories of genocide, colonization, homophobia and sexism.

- Oppression breeds multi-generational wisdom, desire and tactics of subversion. While opportunities for youth development are severely mal-distributed, these projects assume that knowledge is widely distributed and most acutely voiced by those young people who have been most denied. While public institutions have historically and systematically betrayed communities of poverty and color, from within these communities, youth and elders harbor critical wisdom, desire and tactics of subversion.

- Research grounded in inquiry and action. PAR is founded on the principle that social inquiry projects should be rooted in theory and focused on changepolitical, theoretical, cultural, institutional, community and/or interpersonal. The participatory action research projects described in this volume have been designed to generate data to be of use in city-wide education organizing campaigns; activating educators to re-think tracking; challenging scholars on their demonizing representations of "the underclass," and inviting high schools and colleges to re-consider the contributions that marginalized students offer their campuses.

- Projects rooted in ethics and responsibility. Finally, the projects detailed here carry a deep sense of responsibility for and with schools and communities, especially communities of color, poverty and systematic disenfranchisement. Even when located in relatively privileged settings, PAR seeks to speak aloud the consequences of systematic structural and symbolic violence.

The six essays in this volume are a must read; actually they are a must teach in courses on educational foundations; the politics of race and education; educational 
policy; multi-culturalism; social justice, and in courses on research epistemology and method. As you turn the pages, you will encounter the thrill and angst of deeply participatory research projects designed to tell a story of injustice and defiance brewing in and around urban America. Each essay, previewed below, is organized around a key dilemma of politics/theory/method that knots up in participatory work, with critical race theory, within contentious social spaces.

The volume opens with Brett Stoudt's essay on PAR undertaken with elite White boys and their educators, all his co-researchers in a private boys' school. Together they interrogate how their privileged social class, white skin and gender are reproduced in their schools and how that reproduction might be interrupted, through empirical analyses of hazing, bullying and what Stoudt calls "violence." Stoudt writes eloquently and thoughtfully on the ways in which privilege laminates itself in denial and refuses to reflect on its own enactments of violence. Although those of privilege relentlessly defend their own innocence ("It's just a joke!"), Stoudt works with the young men to pry open their definitions of bullying and hazing. He insists that they see themselves and each other, as capable of being victims, but also perpetrators and observers of violence. And then he invites them to study these dynamics in their own school.

Stoudt traces the journey of this ambitious and sticky PAR project within an institution of substantial privilege. By daring to speak about violence and hypermasculinity within the belly of power, Stoudt raises up ethical and methodological questions of how one might conduct PAR within elite institutions, designed to lift up the dirty linens that all know but are committed to deny. His essay is a very fine and precise analysis of the ways in which language, audience, products, reception and youth vulnerabilities collude to keep the "message" tame. He leaves us with the dilemma of how researchers might sustain fragile collaborations with privileged institutions, even as we generate data that breach the well protected ideologies of tradition, honor, merit and integrity.

At the other end of the class spectrum, Yasser Payne produces a paper with a very different call; a call for scholars to go to the community, the streets, and create PAR projects for local justice needs. Grounded in Payne's theorizing about the streets as a site of resiliency, Payne has authored a significant methodological journey through a PAR project conducted with men of African-descent, living in poverty in Harlem and Paterson New Jersey, who lead a street life. Documenting the men's complex negotiations of poverty and racism in a nation that has walked away from them and their communities, Payne with his co-researchers, produces a counter-narrative about the street love shared and experienced by these men. With a fierce commitment to restore humanity to the social science representations of these men, Payne documents the lives and ethics of the streets. He refuses to reproduce the academic binary of morality versus criminality. Instead he reveals how profoundly economic and racial injustices penetrate the souls, lives and the loves of these men. Making visible the threads that tether the men to an economy that renders them disposable, Payne insists that readers disrupt their stereotypes and re-meet these men as fathers, brothers, sons and men who care deeply about community, the children and a better tomorrow.

Eve Tuck's essay moves the volume toward a thoughtful reflection on the middle-term in PAR; that is the action. Tuck describes two yPAR projects: 
Collective of Researchers on Educational Disappointment and Desire (CREDD), which involves a study of the use and overuse of the General Educational Development (GED) credential option in New York City public schools, focusing on the value of the GED and push out practices in NYC schools, and Youth Researchers for a New Education System (YRNES) which began as part of a citywide campaign of adults and youth to investigate timely questions of mayoral control over schools (which is about to sunset) and the need for human rights based public schooling.

Tuck writes on "the urgency of our data, including a dismal $43 \%$ graduation rate in NYC and students' reports of urine on the floor and crumbling walls in their schools render this statement less than satisfying...it's hard to be patient for reform." Working with Indigenous theory and Craig Gingrich-Philbrook's writings on the double-bind, Tuck asks how researchers can join with activists to provoke change in the public education system so obviously rotting and yet so essential to poor communities of color? Tuck insists that readers confront the historic relations of research and colonization and then imagine research as a practice grounded in sovereignty, contention, balance and relationship.

While Tuck argues for sovereignty, Jen Ayala takes us into the treacherous spaces of institutional borderlands-where the academic rituals of research confront the urgency of inquiry-inspired protest; where the IRB presumes confidentiality and research speak-outs require naming names; where youth researchers dare to study and speak truth to audiences who sit arms folded and angry faced, refusing to listen. Ayala draws theoretically from Gloria Anzaldua as she explains how borderlands scholarship shaped her research design, sampling, methods and analysis with her high school and college age co-researchers.

With intelligent reflection and political passion, Ayala then reflects on how she travels with her youth collaborators through the checkpoints between institutions. She relies upon Anzaldua's mestiza consciousness as they navigate through crossinstitutional politics, never letting the youth drown. She helps readers consider our responsibilities, as researchers working in the borderlands of institutional and community life, with youth as allies, in waters we know to be easily threatened by social critique. She asks simply and profoundly-To whom are we responsible? And then shows us how.

Monique Guishard carries the work of PAR into a community based parents' organization in the South Bronx, MOM-Mothers on the Move. She has crafted an intellectually and politically provocative multi-logue between Paolo Freire's theories of critical consciousness, Black feminist thought and the lived experiences and beliefs of her PAR collective of young people and activist elders. Guishard reflects, further, on her own difficulties in finding a footing as she vacillates between "great theorists" and the perspectives of the mothers and youth of MOM. Inviting us to eavesdrop on her own process, Guishard comes to understand that in solidarity with Black feminist thought and the MOM members and youth, she must delicately amend Freire's thinking. Eventually Guishard challenges the assumed linear progression of consciousness and writes, instead, about moments of critical consciousness and revolutionary love as they are lived, narrated and enacted, in real lives, over time. 
Offering us a two-generational analysis of mis-education and organizing, outrage and joy in the Bronx, Guishard retheorizes radical thought and action, on the ground.

The volume ends with María Elena Torre who elucidates the overlap and tensions between Participatory Action Research and Critical Research Theory. Torre is interested in the radical possibilities that are electrified by PAR in the contact zone, where differentially positioned young people come together across the lines of race, ethnicity, gender, sexuality, neighborhood, (dis)ability and class, to study public education, contest what is and to imagine what could be. Documenting a large urban-suburban youth-led survey and focus group study of the "opportunity gap," and then a spoken word performance of the data gathered from thousands of urban and suburban youth, Torre asks us to see what happens "between"; when critical intimacy crosses borders that are rarely trespassed; to witness how "contact" can endanger and transform, connect and repulse, reproduce existing injustices and birth possibilities heretofore unimagined.

$* * *$

As a volume, these essays insist that researchers engage with schools and communities for economic, political, racial and gendered justice. The writers seek to instill in readers a collective sense of urgency, responsibility and ethics; hoping to whet an appetite for deep, participatory research collaborations with communities under siege.

With pride and awe, I invite you to turn the page and dive in.

\section{References}

Appadurai, A. (2006). The right to research. Globalisation, Societies and Education, 4(2), 167-177.

Cahill, C. (2007). Doing research with young people: Participatory research and the rituals of collective work. Children's Geographies, 5(3), 297-312.

Fine, M., Tuck, E., \& Zeller-Berkman, S. (2007). Do you believe in Geneva? In C. McCarthy, A. Durham, L. Engel, A. Filmer, M. Giardina, \& M. Malagreca (Eds.). Globalizing cultural studies (pp. 493-525). New York: Routledge. Reprinted in N. Denzin, L. T. Smith, \& Y. Lincoln, Handbook of critical and indigenous knowledges. Beverley Hills: Sage Publications.

Hickey, S., \& Mohan, G. (2004). Participation: From tyranny to transformation. London: ZED Books.

Lykes, M. B. \& Mallona, A. (2008). Towards transformational liberation: Participatory and action research and praxis. In Reason \& H. Bradbury (pp. 106-120).

Rahman, A. (2008). Some trends in the praxis of PAR. In Reason \& H. Bradbury (pp. 49-62).

Reason, P., \& Bradbury, H. (2008). Handbook of action research. London: Handbook of action research: Participative inquiry and practice (2nd ed.). London: Sage Publication.

Swantz, M. L. (2008). Participation action research as practice, In Reason \& H. Bradbury (pp. 31-48).

Torre, M. E., Fine, M., Alexander, N., \& Genao, E. (2005). "Don't die with your work balled up in your fists": Young urban women resisting the passive revolution. In N. Way \& B. Leadbetter (Eds.), Urban girls (pp. 221-242). New York: NYU Press. 